\title{
Did Hospital Admissions Caused by Respiratory Infections and Asthma Decrease During the COVID-19 Pandemic?
}

\section{COVID-19 Pandemisinde Solunum Yolu Enfeksiyonları ve Astıma Bağlı Hastane Başvuruları Azaldı mı?}

\section{(D) Zeynep Reyhan ONAY, (D) Deniz MAVI, (D) Yetkin AYHAN, (D) Sinem CAN OKSAY, (D) Gulay BILGIN, (D) Saniye GIRIT}

Istanbul Medeniyet University Faculty of Medicine, Department of Pediatric Pulmonology, Istanbul, Turkey

\begin{abstract}
Objective: Despite maximum isolation measures taken during the coronavirus disease-2019 (COVID-19) pandemic, the workload of health institutions has increased. Consequently, changes in the number of admissions in clinics and emergency departments by disease groups have been observed. We aimed to quantitatively investigate the changes in the frequency of respiratory infections and asthma in the pediatric population during the COVID-19 pandemic.

Methods: We analyzed electronic medical record data of patients who were admitted to the emergency department (ED), outpatient and inpatient clinics, and pediatric intensive care unit (PICU) because of influenza, upper and lower respiratory tract infections (URTI, LRTI), acute bronchiolitis, and asthma during the two-year period (one year preCOVID period and first year of the pandemic).

Results: There were 96,648 admissions in the pre-COVID period and 15,848 during the pandemic. We observed a decline in ED admissions (-73\%), outpatient clinic visits $(-70 \%)$, hospitalizations $(-41.5 \%)$, and PICU admissions $(-42 \%)$. While the admission rates of patients with influenza [from $4.26 \%$ to $0.37 \%(p=0.0001)$ ] and URTI [from $81.54 \%$ to $75.62 \%$ $(p=0.0001)]$ decreased, the ratio of the number of admissions to the total number of admissions due to LRTI [from $8.22 \%$ to $10.01 \%(p=0.0001)$ ], acute bronchiolitis [from $2.76 \%$ to $3.07 \%(p=0.027)$ ], and asthma [from $5.96 \%$ to $14 \%(p=0.0001)]$ increased.

Conclusions: The decrease in viruses that cause acute bronchiolitis and asthma attacks lead to a reduction in admissions to ED of this patient group. The fact that parents preferred not to admit their child in ED during this period may have paved the way for the development of more severe LRTIs.

Keywords: Acute bronchiolitis, asthma, children, COVID-19, respiratory tract infections
\end{abstract}

\section{öz}

Amaç: Koronavirüs hastalığı-2019 (COVID-19) pandemisi döneminde alınan maksimum izolasyon önlemlerine rağmen sağlık kurumlarının hasta yoğunluğu artmıştır. Bununla ilişkili olarak bazı hastalık gruplarının başvurdukları bölüm ve başvuru sayılarında değişiklikler olduğu gözlemlenmiştir. Çalışmamızda, pediatrik solunum yolu enfeksiyonları ve astım sıklığında COVID-19 dönemine özgü değişiklikleri nicel olarak araştırmayı hedefledik.

Yöntemler: Hastanemiz çocuk acil, pediatri kliniği ve polikliniği ve çocuk yoğun bakım ünitesindeki (ÇYBÜ) iki yıllık dönemde (preCOVID bir yıl ve COVID pandemisinin ilk yılı); influenza, üst ve alt solunum yolu enfeksiyonları (ÜSYE, ASYE), akut bronşiyolit ve astım tanıları alan çocukların elektronik tıbbi kayıt verileri incelendi.

Bulgular: Pandemi öncesindeki bir yıllık dönemde 96.648 ve pandeminin ilk yılında 15.848 çocuk hasta başvurusu mevcuttu. Pandemi döneminde toplam acil servis başvurularında \%73, toplam poliklinik başvurularında \%70, toplam hastane yatış sayısında \%41,5 ve toplam ÇYBÜ yatış sayısında \%42 düşüş olduğu tespit edildi. Influenza $[\% 4,26$ 'dan \%0,37'ye $(p=0,0001)]$ ve ÜSYE [\%81,54'ten \%75,62'ye $(p=0,0001)]$ başvurularının toplam başvuru sayısı içindeki oranları azalırken, ASYE $[\% 8,22$ 'den $\% 10,01$ 'e $(p=0,0001)]$, akut bronşiyolit $[\% 2,76$ 'dan \%3,07'ye $(p=0,027)]$ ve astım [\%5,96'dan \%14'e $(p=0,0001)]$ tanılarının toplam başvuru sayısı içindeki oranları artmıştır.

Sonuçlar: Genellikle akut bronşiyolit ve astım ataklarına neden olan virüslerin azalması bu hasta grubunun acil servise başvurularını azaltmıştır. Bu dönemde ebeveynlerin acil servisi tercih etmemeleri daha şiddetli ASYE'nin gelişmesine zemin hazırlamış olabilir.

Anahtar kelimeler: Akut bronşiyolit, astım, çocuklar, COVID-19, solunum yolu enfeksiyonları

Presented in: The study was presented orally in the $24^{\text {th }}$ Turkish Thoracic Society Congress on November 17-21, 2021.

Publication: The preprint version of the article was previously shared with "Authorea" with DOI:10.22541/au.163403131.16322634/vl. Has not been published in another journal.

Address for Correspondence: S. Girit, Istanbul Medeniyet University Faculty of Medicine, Department of Pediatric Pulmonology, Istanbul, Turkey

E-mail: saniyegirit@gmail.com ORCID ID: orcid.org/0000-0001-7556-6568
Received: 27 November 2021

Accepted: 01 February 2022

Online First: 18 February 2022 


\section{INTRODUCTION}

Coronavirus disease-2019 (COVID-19) started in Wuhan, China in December 2019 and spread all over the world. The World Health Organization declared the pandemic on March 11, 2020, as it became a global public health problem'. Currently, more than 190 million and 5.5 million cases of severe acute respiratory syndrome coronavirus- 2 infection have been reported worldwide and in Turkey, respectively ${ }^{2}$. The virus is mainly transmitted by droplets and by touching the mouth, eyes, or nasal mucosa after contact with droplets that infected individuals spread by coughing and sneezing'.

Since respiratory tract infections are often transmitted by droplets and aerosols, general protective measures such as hand hygiene, social distancing, keeping optimal room temperature and humidity levels, and frequent ventilation of closed areas have been recommended for many years in clinical practice. Furthermore, studies have shown that wearing of personal protective equipment such as surgical masks and N95 masks, which have been used increasingly since the HINl pandemic in 2009, effectively and correctly using masks, and practicing hand hygiene are crucial in preventing influenza transmission ${ }^{3}$. Thus, the use of masks and social distancing measures have been applied globally since the COVID-19 pandemic began.

During the COVID-19 pandemic, lockdown rules were introduced in Turkey on March 16, 2020, and COVID19-related restrictions were applied to all citizens ${ }^{4}$. Nationwide lockdown undertakings initiated the closure of schools and restaurants, restriction of intercity travel, recommendation of work-from-home setting, recommendation for residents under 18 and over 65 to stay at home, and obligation to wear mask and practice social distancing to avoid the transmission of COVID-194.

During the COVID-19 pandemic, we observed a significant decrease in respiratory diseases in clinical practice compared with previous years. This could be the result of measures mentioned previously. We aimed to determine the prevalence of inpatient and outpatient hospital visits for respiratory illnesses in children between one year before and during the first year of the COVID-19 epidemic.

\section{MATERIALS and METHODS}

We conducted this retrospective study in a single center at a university hospital in Istanbul, Turkey, to which both adults and children are admitted. We analyzed the electronic medical record data of the pediatric emergency department (ED), general pediatric and pediatric pulmonology outpatient clinics, general pediatric and pediatric pulmonology inpatient clinics, and pediatric intensive care unit (PICU) between March 17, 2019, and March 31, 2021. We collected data on ED visits and in- and outpatient clinic visits from before and after the declaration of the emergency about COVID-19 on March 16, 2020 in Turkey. The period from April 1, 2019, to March 16, 2020, was considered the pre-COVID period, and the period from March 17, 2020, to March 31, 2021 was considered the COVID-19 pandemic period. Thus, one year before and one year after the onset of the COVID-19 outbreak in Turkey were covered in the study to determine the variations in frequency across respiratory illnesses in relation to COVID-19.

We divided the patients' diagnoses into six main classes according to the International Code of Diseases, $10^{\text {th }}$ edition coding (J00-J99) as follows: acute upper respiratory tract infections (URTIs) (J00-J06), influenza due to identified influenza virus (J10), influenza due to unidentified influenza virus ( $\mathrm{Jl1})$, acute lower respiratory tract infections (LRTIs) (J12-J21), acute bronchiolitis (J21), and asthma (J45). We divided the diagnosis of influenza into two separate groups: identified and unidentified (Table 1$)^{5}$.

Children aged 0-18 years who were admitted to ED, general pediatric and pediatric pulmonology outpatient clinics, general pediatric and pediatric pulmonology inpatient clinics, and PICU were included the study. We recorded the number of admissions in two periods indicating the total number and the number of admissions to ED, outpatient clinics (pediatrics and pediatric pulmonology), inpatient clinics (pediatric and pediatric pulmonology), and PICU. Admission rates were given as the ratio of the number of admissions to the department to the total number of admissions in the same period. We also recorded the gender and age of the patients.

\section{Statistical Analysis}

In this study, we performed statistical analyses using Number Cruncher Statistical System 2007 Statistical Software (Utah, USA) package program. In the evaluation of the data, besides descriptive statistical measures (mean, standard deviation, frequency, and percentage distributions), we examined the distribution of variables using the Shapiro-Wilk normality test; we used the independent t-test for comparing normally distributed variables in pairs; we used the chi-square test for comparing qualitative data. The results were evaluated at the significance level of $p<0.05$. 


\begin{tabular}{|c|c|}
\hline Diagnosis & ICD-10 codes \\
\hline \multirow{7}{*}{ Acute upper respiratory tract infection } & Acute nasopharyngitis (JOO) \\
\hline & Acute sinusitis (J01) \\
\hline & Acute pharyngitis (J02) \\
\hline & Acute tonsillitis (J03) \\
\hline & Acute laryngitis and tracheitis ( $\mathrm{J} 04)$ \\
\hline & Acute obstructive laryngitis (croup) and epiglottitis (J05) \\
\hline & Acute upper respiratory infections of multiple and unspecified sites (J06) \\
\hline Influenza due to identified influenza virus & $\mathrm{J} 10$ \\
\hline Influenza due to unidentified influenza virus & וl \\
\hline \multirow{9}{*}{ Acute lower respiratory tract infection } & Viral pneumonia, not elsewhere classified (J12) \\
\hline & Pneumonia due to Streptococcus pneumoniae (J13) \\
\hline & Pneumonia due to Hemophilus influenzae (J14) \\
\hline & Bacterial pneumonia, not elsewhere classified (J15) \\
\hline & $\begin{array}{l}\text { Pneumonia due to other infectious organisms, not elsewhere classified } \\
\text { (J16) }\end{array}$ \\
\hline & Pneumonia in diseases classified elsewhere (J17) \\
\hline & Pneumonia, unspecified organism (J18) \\
\hline & Acute bronchitis (J20) \\
\hline & Acute bronchiolitis (J21) \\
\hline Acute bronchiolitis & $J 21$ \\
\hline Asthma & $J 45$ \\
\hline \multicolumn{2}{|l|}{ ICD-10: International Code of Diseases, $10^{\text {th }}$ edition } \\
\hline
\end{tabular}

\section{Ethical Approval}

This study was conducted in accordance with the amended Declaration of Helsinki and approved by the Ethics Committee of the Istanbul Medeniyet University Goztepe Training and Research Hospital on February 24, 2021 (decision no: 2021/0159).

\section{RESULTS}

There were 112,496 inpatient and outpatient clinic visits in the 2 year period for respiratory illnesses: 96,648 (85.91\%) were pre-COVID and 15,848 (14.08\%) were during the COVID-19 pandemic. We noticed that the total admission rate decreased by $70.82 \%$ during the pandemic $(p=0.0001)$.

The number of admissions to ED, inpatient and outpatient clinics, and PICU during the pandemic decreased by $73 \%, 41.53 \%, 70.22 \%$, and $41.90 \%$, respectively $(p=0.0001, p=0.0001, p=0.0001$, and $p=0.0001)$.

The ratio of the number of admissions to ED decreased from $65.70 \%$ to $62.51 \%$, while those of inpatient and outpatient clinic visits and PICU admissions increased during the COVID-19 pandemic [from $0.049 \%$ to $1.23 \%$ ( $p=0.0001$ ), from $33.68 \%$ to $35.94 \%(p=0.0001)$, and from $0.13 \%$ to $0.33 \%(p=0.0001)$, respectively].

The mean age of the patients during the pandemic was $7.34 \pm 5.20$ and $6.37 \pm 4.56$ years during the pre-COVID period. Mean age was significantly higher during the pandemic $(p=0.0001)$. In terms of gender of patients, $45.7 \%$ of the patients were male during the pandemic, while $44.8 \%$ were male during the pre-COVID period $(p=0.02)$. The details of the data collected are given in Table 2.

\section{Change in Admissions of Influenza}

Influenza identified was never detected during the pandemic period, while cases of unidentified influenza declined by $97.22 \%$. The ratio of the number of admissions to ED due to identified influenza decreased [from $97.26 \%$ to $87.93 \%(p=0.0001)$ ], while those of inpatient and outpatient clinic admissions increased [from $0.05 \%$ to $1.72 \%(p=0.024)$ and from $2.62 \%$ to $10.34 \%(p=0.001)$, respectively]. 


\begin{tabular}{|c|c|c|c|c|}
\hline Hospital admissions & Pre-COVID period ${ }^{a}$ & COVID-19 period ${ }^{\mathrm{b}}$ & $\%$ change & $\mathbf{p}$ \\
\hline Total number, n (\%) & $96,648(100.00)$ & $15,848(100.00)$ & -70.82 & 0.0001 \\
\hline ED admissions, $\mathrm{n}(\% \mathrm{c})$ & $63,494(65.70)$ & $9,906(62.51)$ & -73.01 & 0.0001 \\
\hline Outpatient clinic visits, $\mathrm{n}(\% \mathrm{c})$ & $32,555(33.68)$ & $5,695(35.94)$ & -70.22 & 0.0001 \\
\hline Inpatient clinic visits, $\mathrm{n} \mathrm{( \% c)}$ & $472(0.049)$ & $195(1.23)$ & -41.53 & 0.0001 \\
\hline PICU admissions, n (\%) & $127(0.13)$ & $52(0.33)$ & -41.90 & 0.0001 \\
\hline Gender (male), n (\%c) & $52,408(45.77)$ & $8,749(44.79)$ & -72.34 & 0.02 \\
\hline Age, mean \pm SD & $6.37 \pm 4.56$ & $7.34 \pm 5.20$ & 13.22 & 0.0001 \\
\hline \multicolumn{5}{|c|}{ 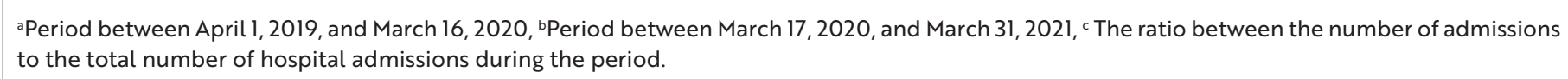 } \\
\hline \multicolumn{5}{|c|}{$\begin{array}{l}\text { PICU: Pediatric intensive care unit, SD: Standard deviation, LRTI: Lower respiratory tract infection, COVID-19: Coronavirus disease-2019, URTI: Upper } \\
\text { respiratory tract infection, ED: Emergency department }\end{array}$} \\
\hline
\end{tabular}

\section{Change in Admissions of Respiratory Infections}

The ratio of the number of admissions due to URTI to the total number of hospital admissions dropped from $81.54 \%$ in the pre-COVID period to $75.62 \%$ during the pandemic $(p=0.0001)$. The ratio of the number of outpatient clinic visits decreased [from $31.89 \%$ to $25.43 \%$ $(p=0.0001)]$, while those of $E D$, inpatient clinics, and PICU admissions increased [from 68.05\% to $74.36 \%$ $(p=0.0001)$, from $0.04 \%$ to $0.16 \%(p=0.0001)$, and from $0.02 \%$ to $0.05 \%(p=0.042)$, respectively]. Also, the average age of the patients with URTI significantly increased from $6.48 \pm 4.57$ to $7.19 \pm 5.23$ years $(p=0.0001)$.

The rate of LRTI during the pandemic increased to $10.01 \%$ from $8.22 \%$ in the pre-COVID period $(p=0.0001)$. The ratio of the number of admissions to inpatient and outpatient clinics and PICU increased [from $5.25 \%$ to $10.14 \%(p=0.0001)$, from $47.25 \%$ to $55.07 \%(p=0.0001)$, and from $1.26 \%$ to $2.46 \%$ ( $p=0.0001$ ), respectively], while that of ED admissions decreased [from $45.95 \%$ to $32.33 \%$ $(p=0.0001)]$. Moreover, the mean age of children with LRTI significantly increased from $4.78 \pm 4.25$ to $6.58 \pm 5.35$ years $(p=0.0001)$.

\section{Change in Admissions of Acute Bronchiolitis}

The prevalence rate of acute bronchiolitis was 3.07\%, with 487 cases during the pandemic. On the other hand, the prevalence rate was $2.76 \%, 2,669$ cases in the preCOVID period. The rate decreased significantly during the pandemic $(p=0.027)$. The rate of outpatient clinic visits due to acute bronchiolitis increased from $53.28 \%$ to $62.22 \%(p=0.003)$, and admissions to ED decreased from
$38.33 \%$ in the pre-COVID period to $28.13 \%(p=0.0001)$ during the pandemic. We found no significant changes in admissions to inpatient clinics and PICU during the pandemic ( $p=0.583$ and $p=0.612$, respectively).

\section{Change in Admissions of Asthma}

The prevalence rate of asthma during the pandemic was $14 \%$ with 2,218 cases, which is significantly higher than the rate of $5.9 \%$ with 5,761 cases during the preCOVID period $(p=0.0001)$. We noticed a decrease in ED admissions (from $38.15 \%$ to $19.39 \%$ ) and an increase in outpatient clinic visits (from $61.40 \%$ to $79.67 \%$ ), inpatient clinics visits (from $0.31 \%$ to $0.32 \%$ ), and PICU admissions (from $0.14 \%$ to $0.32 \%$ ) due to asthma during the pandemic. We found no differences in the number of admissions to inpatient clinics and PICU $(p=0.068$ and $p=0.179$, respectively), but we found a significant decline in the numbers of ED admissions (from $38.19 \%$ to $19.39 \%$ ) and outpatient clinic visits (from $61.40 \%$ to $79.67 \%$ ) ( $p=0.0001$ and $p=0.0001$, respectively).

The data collected on the diagnoses are shown in Table 3.

Distribution of ED admissions, outpatient and inpatient clinic visits, and PICU admissions before and during the pandemic according to the diagnoses is given in Figure 1.

The rates of hospital admission due to influenza, URTI, LRTI, acute bronchiolitis, and asthma before and during the pandemic are given in Figure 2. 


\begin{tabular}{|c|c|c|c|c|}
\hline Diagnosis & Pre-COVID perioda $n$ (\%) & COVID-19 period ${ }^{\mathrm{b}} \mathrm{n}(\%)$ & \% change & $\mathbf{p}$ \\
\hline Influenza, identifiedc & $14(0.01)$ & $0(0)$ & -100.00 & 0.129 \\
\hline Influenza, unidentified ${ }^{c}$ & $4,118(4.26)$ & $58(0.37)$ & -97.22 & 0.0001 \\
\hline URTIc & $78,810(81.54)$ & $11,985(75.62)$ & -73.60 & 0.0001 \\
\hline LRTI & $7,945(8.22)$ & 1,587 (10.01) & -66.70 & 0.0001 \\
\hline Acute bronchiolitis ${ }^{c}$ & $2,669(2.76)$ & $487(3.07)$ & -69.14 & 0.027 \\
\hline Asthmac & $5,761(5.96)$ & $2,218(14.00)$ & -44.40 & 0.0001 \\
\hline \multicolumn{5}{|c|}{$\begin{array}{l}\text { aPeriod between April 1, 2019, and March 16,2020, }{ }^{b} \text { Period between March 17, 2020, and March 31, 2021, }{ }^{\mathrm{c}} \text { The ratio between the number of admission } \\
\text { and the total number of hospital admissions during the period. }\end{array}$} \\
\hline \multicolumn{5}{|c|}{ URTI: Upper respiratory tract infection, LRTI: Lower respiratory tract infection, COVID-19: Coronavirus disease-2019 } \\
\hline
\end{tabular}

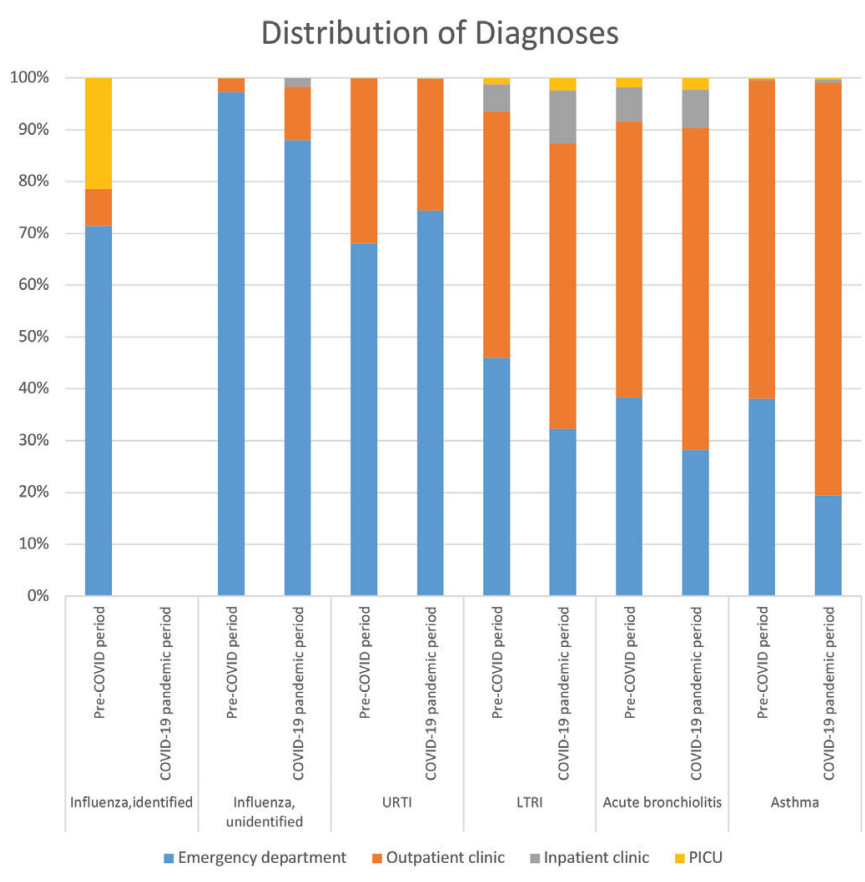

Figure 1. Distribution of emergency department, outpatient clinics, inpatient clinics, and PICU admissions before and during the COVID-19 pandemic according to the diagnosis of children.

COVID-19: Coronavirus disease-2019, URTI: Upper respiratory tract infection, LTRI: Lower respiratory tract infection, PICU: Pediatric intensive care unit

\section{DISCUSSION}

In our study, we detected a $70 \%$ drop in the total number of hospital admissions during the pandemic period compared with the previous year. However, the decrease in hospital admissions by disease groups was respectively higher in influenza, URTI, acute bronchiolitis, LTRI, and asthma (97\%, 73\%, 69\%, 66\%, and 44\%).

Indeed, the pandemic caused a significant reduction in the number of admissions due to respiratory infections

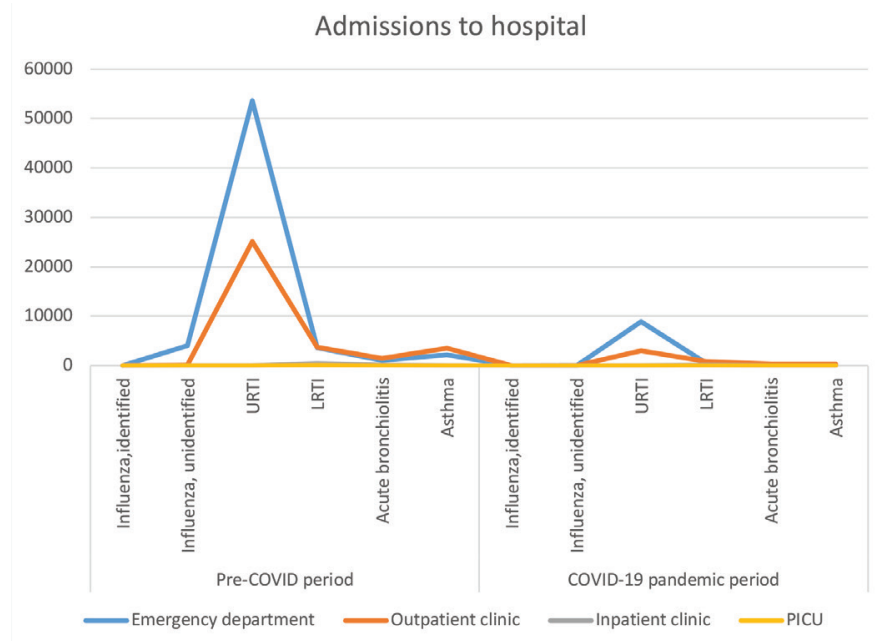

Figure 2. Hospital admission rates due to influenza, URTI, LRTI, acute bronchiolitis, and asthma before and during the pandemic.

COVID-19: Coronavirus disease-2019, URTI: Upper respiratory tract infection, LTRI: Lower respiratory tract infection, PICU: Pediatric intensive care unit

and asthma in children worldwide. Other published studies that confirm our findings have detected a significant decline in respiratory infection cases during the pandemic. Kuitunen et al. ${ }^{6}$ found a more than $20 \%$ decline among respiratory infection cases in ED admissions in the first 6 weeks after the emergency was declared. Lin et al. ${ }^{7}$ also found a nearly 50\% decline in respiratory infection cases among children in ED visits compared with the past 3 years. The reason why these data are much lower than our values may be due to the shorter duration of these studies.

Respiratory infections were the most frequent causes of hospitalization worldwide ${ }^{8}$. The vast majority of RTI cases are caused by viruses. Additionally, respiratory syncytial virus as well as rhinovirus bronchiolitis is a risk 
factor for recurrent wheezing and asthma9. In our study, we found that the rates of admissions to ED due to RTI, bronchiolitis, and asthma decreased globally. The reason for the decline in the rate of these disease groups may be attributed to the decrease in the spread of respiratory tract viruses in the community due to the use of masks, social distancing measures, and closure of schools.

Although we found a dramatic increase in the rate of diagnosis of unidentified influenza during the pandemic, this might be a false increase. Because nasal swab samples for respiratory viruses could not be taken during the pandemic, identified influenza (J1O) could not be diagnosed properly. More cases may have been erroneously diagnosed as unidentified influenza. The cohort study by Song at al. ${ }^{10}$ also found an abrupt decrease in the rate of diagnosis of influenza. This study shows that the cases with identified influenza decreased during the pandemic because of the decrease in transmission.

A study conducted between April and June 2020 found that no child was diagnosed with acute bronchiolitis compared with the previous year without social distancing". Hatoun et al. ${ }^{12}$ found that during the 18 weeks of social distancing, the diagnosis of acute bronchiolitis essentially disappeared. In our study, acute bronchiolitis and LRTI decreased compared with the prepandemic period. However, acute bronchiolitis and latent tuberculosis infection rates among all these disease groups increased respectively from $2.76 \%$ to $3.07 \%$ and $8.22 \%$ to $10.02 \%$ compared with the previous year. In addition, inpatient clinic visits and PICU hospitalizations increased compared with the previous year. This shows that families avoided ED services because of the fear of infection; however, they admitted their children to outpatient clinics when their symptoms progressed, increasing the rate of hospitalization.

In our study, the rate of hospitalization due to unidentified influenza during the pandemic increased compared with that in the pre-COVID period. This may be due to the more severe clinical status of children or the fact that the differential diagnosis of COVID-19 could not be made. For this reason, oseltamivir was also included in the treatment of COVID-19 at the onset of the pandemic ${ }^{13}$.

Papadopoulos et al. ${ }^{14}$ observed a decrease in the frequency of admissions to pediatric asthma clinics, while children with asthma were not affected disproportionately by COVID-19. We found at least some decrease in asthma admissions compared with admissions due to other respiratory tract diseases during the pandemic (44\%).
We noticed a decrease in ED admissions (from 38.15\% to $19.39 \%$ ) and an increase in outpatient clinic visits (from $61.40 \%$ to $79.67 \%$ ). Similar to a previous study, although the rate of general hospital admissions of patients with asthma seems to have decreased, the rate of admission of patients with other respiratory diseases has increased. Although the admissions of patients with asthma to ED decreased, outpatient admissions increased relatively. This may have been caused by the very decrease in viruses that trigger asthma attacks, primarily independent of COVID-19.

Despite being a long-term comparison of the COVID-19 pandemic and pre-pandemic periods, our study had some limitations. During the pandemic, nasal swab samples could not be investigated in our hospital; therefore, we could not analyze the exact causes of respiratory infections such as influenza. Another limitation of the study is that it is a single center study. National and multicenter studies with prospective designs and rich in virological data that study the impact of the pandemic on the prevalence of respiratory illnesses would be more accurate.

\section{CONCLUSIONS}

We found that the rates of admissions to hospital due to RTI, acute bronchiolitis, and asthma dramatically decreased. However, we found that LRTI, acute bronchiolitis, and asthma cases increased relatively compared with others, with even more admissions due to acute bronchiolitis and LRTI.

We can say that the social isolation and contact measures taken during the pandemic reduced viral infections. The decrease in upper respiratory tract viruses, which causes acute bronchiolitis and triggers asthma attacks, has reduced the admissions of this patient group to ED. However, the reluctance of families to go to ED may have led to the development of more severe LRTIs and the increase in patients with uncontrolled asthma.

\section{Ethics}

Ethics Committee Approval: This study was conducted in accordance with the amended Declaration of Helsinki and approved by the Ethics Committee of the Istanbul Medeniyet University Goztepe Training and Research Hospital on February 24, 2021 (decision no: 2021/0159).

Informed Consent: Retrospective study.

Peer-review: Externally and internally peerreviewed. 


\section{Author Contributions}

Concept: Z.R.O., D.M., S.G., Design: Z.R.O., D.M., S.G., Data Collection and/or Processing: Z.R.O., D.M., Y.A., S.C.O., G.B., S.G. Analysis and/or Interpretation: Z.R.O., S.G. Literature Search: Z.R.O., D.M., Y.A., S.C.O., G.B., S.G., Writing: Z.R.O., D.M., Y.A., S.C.O., G.B., S.G.

Conflict of Interest: The authors have no conflict of interest to declare.

Financial Disclosure: The authors declared that this study has received no financial support.

\section{REFERENCES}

1. Ministry of Health, General Directorate of Public Health. COVID-19 (SARS-CoV-2 Infection), General information, Epidemiology, Diagnosis. Scientific Advisory Board Study. Ankara. RT. Ministry of Health. December 7, 2020.p.7. Available from: https://covid19. saglik.gov.tr/Eklenti/39551/0/covid-19rehberigenelbilgilerepide miyolojivetanipdf.pdf

2. Johns Hopkins University Center for Systems Science and Engineering. COVID-19 Dashboard by the Center for Systems Science and Engineering (CSSE) at Johns Hopkins University (JHU). Available from: https://gisanddata. maps.arcgis.com/apps/opsdashboard/index.html\#/ bda7594740fd40299423467b48e9ecf6

3. Bin-Reza F, Lopez Chavarrias V, Nicoll A, Chamberland ME. The use of masks and respirators to prevent transmission of influenza: a systematic review of the scientific evidence. Influenza Other Respir Viruses. 2012;6:257-67.

4. COVID-19 Information. Available from: https://tr.usembassy.gov/ covid-19-information-2/ Last accessed: May 4, 2021.
5. ICD-10 version: 2019. Available from: https://icd.who.int/ browsel0/2019/en\#/X

6. Kuitunen I, Ponkilainen VT, Launonen AP, et al. The effect of national lockdown due to COVID-19 on emergency department visits. Scand J Trauma Resusc Emerg Med. 2020;28:114.

7. Lin $\mathrm{CF}$, Huang $\mathrm{YH}$, Cheng $\mathrm{CY}$, Wu KH, Tang KS, Chiu IM. Public Health Interventions for the COVID-19 Pandemic Reduce Respiratory Tract Infection-Related Visits at Pediatric Emergency Departments in Taiwan. Front Public Health. 2020;8:604089.

8. Galanti M, Birger R, Ud-Dean M, et al. Rates of asymptomatic respiratory virus infection across age groups. Epidemiol Infect. 2019;147:176.

9. Jackson DJ, Gangnon RE, Evans MD, et al. Wheezing rhinovirus illnesses in early life predict asthma development in high-risk children. Am J Respir Crit Care Med. 2008;178:667-72.

10. Song X, Delaney M, Shah RK, et al. Comparison of Clinical Features of COVID-19 vs Seasonal Influenza A and B in US Children. JAMA Netw Open. 2020;3:e2020495.

11. Tsagarakis NJ, Sideri A, Makridis P, et al. Age-related prevalence of common upper respiratory pathogens, based on the application of the FilmArray Respiratory panel in a tertiary hospital in Greece. Medicine (Baltimore). 2018;97:e10903.

12. Hatoun J, Correa ET, Donahue SMA, Vernacchio L. Social Distancing for COVID-19 and Diagnoses of Other Infectious Diseases in Children. Pediatrics. 2020;146:e2020006460.

13. Wati DK, Manggala AK. Overview of management of children with COVID-19. Clin Exp Pediatr. 2020;63:345-54.

14. Papadopoulos NG, Custovic A, Deschildre A, et al. Impact of COVID-19 on Pediatric Asthma: Practice Adjustments and Disease Burden. J Allergy Clin Immunol Pract. 2020;8:2592-9. 